Abstracta Iranica

Revue bibliographique pour le domaine irano-aryen

Volume 29 | 2008

Comptes rendus des publications de 2006

\title{
Les inscriptions syriaques. Paris, 2004. (Études syriaques, 1)
}

\section{Christelle Jullien}

\section{(2) OpenEdition}

1 Journals

\section{Édition électronique}

URL : http://journals.openedition.org/abstractairanica/29722

DOI : 10.4000/abstractairanica.29722

ISSN : 1961-960X

Éditeur :

CNRS (UMR 7528 Mondes iraniens et indiens), Éditions de l'IFRI

\section{Édition imprimée}

Date de publication : 15 mai 2008

ISSN : 0240-8910

\section{Référence électronique}

Christelle Jullien, «Les inscriptions syriaques. Paris, 2004. (Études syriaques, 1) », Abstracta Iranica [En ligne], Volume 29 | 2008, document 264, mis en ligne le 15 septembre 2008, consulté le 26 septembre 2020. URL : http://journals.openedition.org/abstractairanica/29722 ; DOI : https://doi.org/10.4000/ abstractairanica.29722

Ce document a été généré automatiquement le 26 septembre 2020.

Tous droits réservés 


\title{
Les inscriptions syriaques. Paris, 2004. (Études syriaques, 1)
}

\author{
Christelle Jullien
}

Ce premier volume de la série Études syriaques offre une vue d'ensemble sur les inscriptions syriaques, datées $d u V^{e} s$. jusqu'à nos jours, dans les régions de Syrie, Turquie, Liban, Égypte aussi, Iraq, Iran (région d'Urmia), Asie centrale, Chine (stèle de Xi'an) et Inde (Kérala). Pour toutes ces régions, chaque contributeur a en charge la publication du corpus d'inscriptions correspondantes, dans le cadre d'un recueil qui sera édité sous les auspices de l'Académie des Inscriptions et Belles-Lettres. Ce volume de synthèse est utile pour connaître l'histoire de la langue mais aussi le milieu culturel de ces communautés ecclésiales.

\section{INDEX}

Thèmes : 6.3. Autres religions

\section{AUTEURS}

\section{CHRISTELLE JULLIEN}

CNRS - Mondes iranien et indien - Paris 